\title{
5 \\ Dealing with Wicked Global Problems: An Inter-Disciplinary Approach
}

\author{
Bland Tomkinson, Charles Engel, \& Rosemary Tomkinson \\ University of Manchester, UK
}

The world faces a number of complex challenges that are sometimes referred to as 'wicked problems.' Universities have been relatively poor at preparing graduates for such challenges, yet it will be the future professionals who need to tackle the problems. This essay looks at two related projects that have attempted to advance the skills training of graduates for a complex world, in the context of educating engineers and scientists in sustainable development.

A Delphi study conducted in the UK suggested that systemic, student-centred approaches were vital to the appropriate development of undergraduates to become engineers with skills in sustainable development. A pilot project sponsored by the UK Royal Academy of Engineering developed an interdisciplinary course unit, using student-centred principles, to embed the principles of sustainable development, in its broadest sense, in the curricula of engineers and scientists. The essay includes an evaluation of this approach.

\section{Introduction}

G lobal warming has begun to feature strongly in everyday life, but it is by no means the only 'wicked' global problem. The oft-cited Brundtland Report (1987) identifies a number of such issues, including:

- the burden of debt in the developing world, inequitable commercial regulations, and a growing number of the world's population living at or below subsistence level;

- overuse of non-renewable resources, growing competition for limited water supplies, and threats of armed conflict over access to water;

- reduction of biodiversity and continuing desertification;

- pollution of air, water, and soil, affecting the 
global environment and climate change;

- continuing growth of the world's population, coupled with additional economic pressures caused by increased life expectancy; and

- increasing nationalistic, political and religious extremism, terrorism, armed conflict, mass migration and social disruption.

To some, these are problems of global societal responsibility, and to others, problems of sustainability: concepts of sustainable development and global citizenship overlap, which represents many of the complex challenges that the world faces.

We sometimes refer to these issues as 'wicked,' in the sense introduced by Rittel and Webber (1973), whose view of a wicked problem was that it featured many of the aspects of:

- having no definitive formulation;

- having no clear end, no stopping rule;

- having a solution that is 'good or bad' rather than right or wrong;

- having no immediate or ultimate test of its resolution;

- having consequences to every solution - there is no possibility of learning by trial and error;

- not having a well-described set of potential solutions;

- being essentially unique;

- being a symptom of another problem;

- having causes with no unique explanation; and

- bringing expectations that its 'owner' will find the 'right' answer.

Although not all of these have to be present for a problem to be 'wicked,' it is equally clear that many of the issues that we are describing will align with these determinants. Tackling such issues requires a different outlook, and universities have a role in shaping future graduates to face such global challenges.

This essay reflects on the implementation of a project, with financial assistance from the UK Royal
Academy of Engineering, to embed some of these approaches in the curriculum and develop in students the skills necessary for operating in a complex 'wicked' world. To this is added the results of a Delphi consultation (which involves a series of structured conversations between leading experts with the aim of reaching a group consensus - see Delbecq, Van de Ven, and Gustafson (1975) for a description of this approach to garnering expert opinion), supported by the Higher Education Academy's Engineering Subject Centre, designed to elucidate best practices in this area.

\section{Problem-Based and Inter- Disciplinary}

The full story of the philosophy and origins of the pilot module are chronicled elsewhere (e.g. Engel \& Tomkinson, 2006; Tomkinson, Engel, Tomkinson, \& Dobson, 2007; Tomkinson, 2008; Tomkinson, Tomkinson, Dobson, \& Engel, 2008). Two key points to bring out here are the inter-disciplinary nature of the module and its reliance on problembased learning.

A brief look at the Brundtland list (above) will exemplify what is involved in trying to tackle issues on a uni-disciplinary basis, yet we often find that disciplines try to 'own' sustainable development or global citizenship. In Manchester, the concept of an inter-disciplinary approach to wicked global problems goes back to ideas of Charles Engel (2002) directed towards the remediation of complex problems of societal responsibility. The University of Manchester embraced some of these ideas, carrying out development activities with staff and students, but it took the support of the UK Royal Academy of Engineering, following a report on the education of future engineers (Engineering Council, 2004), to prime a pilot module for scientists and engineers.

Ideas about the necessity of an inter-disciplinary approach in resolving complex issues of sustainable development were surfacing in other quarters at much the same time. Hadorn et al. (2006) point to Eric Jantsch's ideas, about the reformation of higher education along trans-disciplinary lines in 
order to co-ordinate activities towards a common good, as far back as 1972 . They suggest that the nature of sustainable development research is predicated on whether the processes concerned have a common understanding, but in a fashion that we would now regard as multi-disciplinary in that it draws only what it needs from contributing disciplines. Davies and Devlin (2007), on the other hand, point to areas where two or more disciplines combine their expertise to address an area of common concern, such as the AIDS pandemic, the water crisis in Australia, and climate change. Brand and Karvonen (2007) suggest that sustainable development poses challenges to the discourse of technical experts and that many existing models do not fit within traditional disciplinary boundaries. In this context, the education of engineers and scientists in sustainable development literacy has to be regarded afresh. Lourdel and colleagues (2005) look at a number of approaches to education for sustainable development for engineers and emphasize the need for a holistic approach: " $[\mathrm{t}]$ heoretical classes are not sufficient. It seems important to help them to transpose theoretical knowledge into professional and day-to-day activities." However, she advocates a variety of student-centred approaches, including simulations, case studies, and cognitive mapping; whereas we confined ourselves to a problem-based approach (for a more detailed explanation of this approach, see Engel et al., 2007).

\section{Curriculum Design}

In our pilot module, the strategy for curriculum design was to set up a detailed, step-by-step process, involving the use of four advisory groups (see Tomkinson, Engel, Tomkinson, \& Dobson, 2007) to:

- define a working definition of 'Sustainable Development';

- identify abilities and skills that ought to begin to be developed in the pilot module in the context of realistic case studies;

- identify how the learning outcomes of this module might be assessed and how successful participation by the students might be recog- nized; and

- monitor and evaluate the process of implementing the pilot module, including how staff commitment to a new approach to teaching and learning might be recognized.

Advisory groups were drawn largely from senior academic staff from the Faculty of Engineering and Physical Sciences, and set up so that each individual had a limited time commitment. In addition to the direct impact on curriculum design, other aims of this approach were to underline the credibility of the profession-based content and to foster an innovative educational approach throughout the faculty. In a slightly later study (Tomkinson, Engel, Tomkinson, \& Lawson, 2008), but concurrent with the implementation of the module, we undertook a Delphi consultation amongst leading scholars in engineering for sustainable development within the UK. The initial round of questions was built, to some extent, on the experience of the advisory groups.

\section{The Delphi Study}

From the Delphi study, the main challenges in sustainable development for engineers were generally seen to be social and political, rather than technical - being socially and politically skilled as well as technically so. There was also a feeling that practicing engineers must confront conservative ideas and reluctance to change in issues of sustainable development. The key responsibilities for young professionals were perceived to be communication followed by the raising of awareness with technical skills. In terms of tasks that newly qualified professionals might be expected to undertake, the chief concerns were in handling complex problems (essentially the wicked problems mentioned above) and in systems modelling. Individual engineering disciplines identified specific tools and techniques that might be expected to be employed (though the number of respondents was too small to make clear distinctions), but another major task was seen as that of participating in change management. Relating all this to the curriculum, the main view was that sustainable development should 
be embedded throughout and student-centred learning methods, particularly role play and case studies, were most appropriate. A significant number of respondents felt that sustainable development should form a compulsory element of the curriculum and others felt that making it compulsory was the only way to get students to take on issues of sustainable development.

The holistic nature of the approach advocated here aligns with our view of an inter-disciplinary approach and the underpinning concept of change management also comes through. Although problem-based learning did not specifically feature in the Delphi exercise, the emphasis on student-centred, experiential methods is broadly in line with this view.

\section{The Pilot Module}

The inter-disciplinary, problem-based module has now been run in two consecutive years. In the first cohort, the participants, arranged in six groups of eight, came from three engineering disciplines and Environmental Sciences. In the second cohort, the numbers doubled and the opportunity extended to students from a greater range of science disciplines, some of whom were studying on joint honours courses (e.g. Mathematics and English). Our goal was to achieve a 'strand' running through all three years of the undergraduate curriculum but pragmatism forced us to start solely with third-year students. This means that they had received two years of conditioning to traditional approaches, causing conflict between assessment for learning and for reward. In each year, the students were presented with five problem scenarios (these are shown in the Appendix) and given, normally, two weeks to complete the task. In many cases, students met between their weekly, twohour timetabled sessions. In designing the exercises, a number of requirements were taken into account:

- problems should be complex or 'wicked';

- scenarios should be in context for a recent graduate;

- exercises should develop skills in the management of change;
- problems should lead students to identify core principles of sustainable development;

- exercises should develop professional skills;

- each exercise should build cumulatively on previous ones;

- wherever possible, issues should be current;

- exercises should foster thinking across disciplinary boundaries;

- students' own questions should lead to integrated learning; and

- formative tests should help students to plan their learning through informal, rapid feedback.

A unique feature of the course unit is the use of postdoctoral research staff as group facilitators. Their role is to help the groups to function, not to undertake active teaching; learning comes from the endeavours of the students themselves. The facilitators received training in problem-based learning and the art of facilitation; the training was also used as a selection mechanism. The facilitators met as a group after their weekly facilitation sessions, and this provided a mechanism for feedback, further development, and monitoring of the facilitators' functioning during their group's sessions.

\section{Assessment and Evaluation}

Assessment methods varied between the two years with the first cohort undertaking four forms of assessment: modified essay questions (see Feletti \& Engel, 1980); a group project report; peer assessment (see Conway, Kember, Sivan, \& Wu, 1993); and facilitator observation. For a single course unit we felt that this was over-assessment, and in the second year, reduced the assessment to three items: a group project report, the mark for which was modified by peer observations, and a reflective portfolio. However, this is still a substantial assessment load for students and staff alike.

The project has been evaluated in a number of ways (these are described more fully in Tomkinson, 2008). During the two years that the pilot 
module ran, students and facilitators took part in nominal group processes (see Delbecq et al., 1975; Mackay, 2003). The student feedback in both years was remarkably similar, particularly in the 'positives': the students' prime item in both years was the interdisciplinary nature of the course unit, together with the development of teamwork skills, the nature of the facilitation, the realistic content of the module, and the methods of assessment.

Assessment also featured on the negative side in both years. This was primarily because the first four exercises were intended to be formative and were not counted as part of the summative assessment process. Neither set of students liked the 9am start. Differences between the two cohorts tended to reflect changes that had been made between years. For example, the introduction of online support, through Blackboard Vista, was met with disapprobation by the students in the second year; whereas the first cohort disliked the number of evaluation questionnaires to which they had been subjected, a feature that was much reduced in the second year.

The facilitators showed similar consistency in views between the years, with problem-based learning, imaginative tasks, and communication skills for the students all featuring positively. The interdisciplinary nature of the module and the development of the facilitators' skills in teaching (actually, supporting learning) also featured strongly. There was more variety in the negative responses of facilitators between the two years, the principal difference being a gripe about pay, which had been reduced between years (the facilitators were already receiving pay as post-doctoral researchers and, in the second year, the university authorities deemed that they should only receive an honorarium). However, in both years, the facilitators were disappointed by the narrow range of disciplines represented in the student group, particularly the lack of any social scientists, and also by the range of topics covered - this is a feature of only using five scenarios. The negative stance of some students towards formative assessment was reflected here, particularly for the second cohort. The introduction of online support in the second year picked up an unfavourable mention of Blackboard Vista with the facilitators, despite a more positive view of the use of
GoogleDocs.

As well as the university's standard student satisfaction questionnaire, we applied a number of instruments designed to check on the students' development over the duration of the course unit: a student self-perception questionnaire, designed by the university's School of Education; a questionnaire based on the Readiness for Inter-professional Learning (RIPL) questionnaire (Mattick \& Bligh, 2006), and a learning styles questionnaire (ETL Project, 2005). These were applied at the beginning and end of the unit. The learning styles questionnaire has also been used in the second year, but the analysis is not yet complete.

The results of the self-perception questionnaire indicated that students felt more confident about their knowledge and skills in this area at the end of the course unit and the learning styles questionnaire showed an increase in the application of 'deep' learning; however, the RIPL questionnaire results showed no significant differences, partly a result of high initial scores. The University's standard questionnaires showed remarkably high student satisfaction on most items in the first year and only slightly less satisfaction in the second: the few dimensions on which the course unit did not score well were those where the questions asked were inappropriate to this approach to learning. In the first year, no students failed the module, but no students achieved a very high mark overall; though, a number achieved high marks on individual components. In the second year, the general range of marks increased, notably with more scores in the higher ranges.

This has been a successful start to a single course unit (it was Highly Commended in the UK's Green Gown Awards 2007-8), but the ideas that it embraces are capable of much wider deployment. Our ideas are not solely confined to education for sustainable development. The core approaches and ideas could prove a useful starting point in redesigning university programmes dealing with complex global issues - specifically based on our curriculum design for active, contextual, cumulative, interdisciplinary, collaborative, and reflective learning. The report of the pilot study (Tomkinson, 2008), and its appendices, are designed to enable others to replicate 
the approach to see to what extent the educational approach is transferable. A further report, following a second year of operation, is expected during 2009.

\section{Global Citizenship or Sustainable Development: Does It Matter?}

Clearly, there are 'wicked' global issues that do matter to each and every on of us. Also, higher education has a role to play in working towards remediation of these problems, but, does it matter what we call it? What we have set out to achieve with our students is essentially a portmanteau of knowledge and skills that can help in tackling complex problems and in helping to manage change: we have called this 'sustainable development' but other titles would be equally fitting. In our view, the key to the future of higher education is in educating young people in a realistic way, in inter-disciplinary groups using problem-based learning approaches.

\section{References}

Brand, R. \& Karvonen, A. (2007). The ecosystem of expertise: Complementary knowledges for sustainable development. Sustainability: Science, Practice, and Policy, 3(1), 21-31.

Brundtland, G.H. (1987). Our common future. New York: United Nations.

Conway, R., Kember, D., Sivan, A., \& Wu, M. (1993). Peer assessment of an individual's contribution to a group project. Assessment and Evaluation, 18(1) 45-56.

Davies, M. \& Devlin, M. (2007). Interdisciplinary higher education: Implications for teaching and learning. Retrieved June 2, 2008, from the Melbourne Centre for the Study of Higher Education Website: http://www.cshe.unimelb.edu.au/pdfs/InterdisciplinaryHEd.pdf

Delbecq, A.L., Van de Ven, A.H., \& Gustafson,
D.H. (1975). Group techniques for program planning: A guide to nominal group and Delphi processes. Glenview: Scott, Foresman and Company.

Engel, C.E. (2002). Towards a European approach to an enhanced education of the health professions in the $21^{\text {st }}$ Century. London: CAIPE.

Engel, C.E. \& Tomkinson, B. (2006). Changing higher education to face the global challenges of sustainability. In L. Hunt, B. Tomkinson, \& A. Bromage (Eds.), Realities of educational change in higher education (pp. 156-266). Falmer: Routledge.

Engel C.E., et al. (2007). Whole system approach to problem-based learning in dental, medical, and veterinary sciences: A guide to important variables. Retrieved January 19, 2008, from the Manchester Centre for Excellence in Enquirybased Learning Website:www.campus.manchester.ac.uk/ceebl/resources/resourcepacks/ pblsystemapproach_v1.pdf

Engineering Council UK. (2004). UK standard for professional engineering competence: Chartered engineer and incorporated engineer standards. London: Engineering Council.

ETL Project. (2005). Shortened experiences of teaching and learning questionnaire. Retrieved February 13, 2007, from http://www.tla.ed.ac. uk/etl/docs/SETLQ.pdf

Feletti, G.I. \& Engel, C.E. (1980). The modified essay question for testing problem-solving skills. The Medical Journal of Australia, 1(2), 79-80.

Hadorn, G.H., Bradley, D., Pohl, C., Rist, S., \& Wiesmann, U. (2006). Implications of transdisciplinarity for sustainability research. Ecological Economics, 60, 119-128.

Lourdel, N., Gondran, N., Laforest, V., \& Brodhag, C. (2005). Introduction of sustainable devel- 
opment in engineers'curricula: Problematic and evaluation methods. International Journal of Sustainability in Higher Education, 6.3, 254-264

Mackay, S. (2003). Problem-based learning in radiographer education: Testing the water before taking the plunge. In B. Smith and B. Tomkinson (Eds.), Critical encounters: Scholarly approaches to teaching and learning. York: LTSN Generic Centre.

Mattick, K. \& Bligh, J. (2006). Getting the measure of inter-professional learning. Medical Education, 40, 399-400.

Rittel, H. \& Webber, M. (1973). Dilemmas in a general theory of planning. Policy Sciences, 4, 155-169.

Tomkinson, B., Engel, C.E., Tomkinson, R., \& Dobson H. (2007). Introducing an interdisciplinary professional course on sustainable development into engineering programmes. In W. Aung et al. (Eds.), Innovations 2007: World innovations in engineering education and research. Redding CT, Begell House.

Tomkinson, B. (Ed.). (2008). Educating engineers for sustainable development: Report of a royal academy of engineering sponsored pilot study. Retrieved April 29, 2008 from the University of Manchester Website: http://www.eps.manchester.ac.uk/tlc/sd/

Tomkinson, B., Tomkinson, R., Dobson, H., \& Engel, C. (2008). Education for sustainable development - an interdisciplinary pilot module for undergraduate engineers and scientists. International Journal of Sustainable Engineering, 1(1).

Tomkinson, R., Engel, C., Tomkinson, B., \& Lawson, A. (2008). Education for sustainable development in engineering: Report of a Delphi consultation. Retrieved May 30, 2008, from the Loughborough, Engineering Subject Centre Website: http://www.engsc.ac.uk/downloads/scholarart/delphi-consultation.pdf

\section{Biographies}

Bland Tomkinson is the University Adviser for Pedagogic Development at the University of Manchester, United Kingdom. His current role has two principal aspects: first is the development of academic staff and others who teach, and second, the encouragement of research and development into teaching and learning. In the latter role, he has engaged on two studies looking at the embedding in the curriculum of education for sustainable development and also smaller studies on the use of portfolios for academic and personnel decision-making.

Charles Engel is a Visiting Academic in the Department of Lifelong and Comparative Education at the Institute of Education, University of London, United Kingdom. His interests include national and international consultancies on curriculum design, problembased learning, assessment of students' progress and achievement and evaluation in medical and health professional education, as well as interdisciplinary and inter-professional approaches, particularly to issues of global societal responsibility.

Rosemary Tomkinson is the Academic Support, Teaching Innovation and Development Adviser in the Faculty of Engineering and Physical Sciences at the University of Manchester, United Kingdom. Prior to this she was the Assistant Director of the Teaching and Learning Support Centre at UMIST. Her academic support role is responsible for the programme of development for new lecturers in the faculty, development of those involved in student support, and encouragement of curriculum design and enhancement. 


\section{Appendix}

\section{Details of Student Problem Scenarios}

\begin{tabular}{|c|c|c|}
\hline 2006-7 & Aspects & Task \\
\hline Wheels & $\begin{array}{l}\text { Implementing change within a company; } \\
\text { sustainability definitions, tools and } \\
\text { techniques; corporate attitudes; } \\
\text { understanding stakeholders' perspectives. }\end{array}$ & $\begin{array}{l}\text { Recommend sustainability initiatives for a } \\
\text { manufacturing company. a consultant's letter } \\
\text { provides a list of projects that students may } \\
\text { decide to investigate and could choose to } \\
\text { include in their plan. }\end{array}$ \\
\hline Shelter & $\begin{array}{l}\text { Implementing change across national } \\
\text { boundaries; impacts of natural disasters on } \\
\text { communities; stakeholder cooperation; } \\
\text { infrastructure and logistics; cultural, etc. } \\
\text { differences; sustainable design. }\end{array}$ & $\begin{array}{l}\text { Develop a strategy for transitional } \\
\text { accommodation (housing, schools, clinics, etc) } \\
\text { after a natural disaster; analyse possible } \\
\text { alternative approaches and propose a sound and } \\
\text { sustainable strategy for their construction; } \\
\text { achieve a realistic and workable balance } \\
\text { between international aid and local skills and } \\
\text { manpower. }\end{array}$ \\
\hline Rules & $\begin{array}{l}\text { Implementing change via regulation; impact } \\
\text { of environmental regulation on different } \\
\text { stakeholders; impact on supply chain; } \\
\text { minimising life cycle impacts. }\end{array}$ & $\begin{array}{l}\text { Provide guidance for small companies regarding } \\
\text { the UK's implementation of new directives } \\
\text { concerning electronic equipment manufacturer; } \\
\text { produce a press release describing how negative } \\
\text { life cycle impacts are minimised by the } \\
\text { directives and identify other stakeholders who } \\
\text { will be impacted by the legislation. }\end{array}$ \\
\hline Energy & $\begin{array}{l}\text { Implementing change through new } \\
\text { technology; cost-benefit analysis; barriers to } \\
\text { new technology; infrastructure support for } \\
\text { new technologies. }\end{array}$ & $\begin{array}{l}\text { Assess social, financial, and environmental } \\
\text { impacts of wind-turbines, solar water heating, } \\
\text { geothermal heat pumps, and photovoltaic cells, } \\
\text { with an initial cost-benefit analysis to determine } \\
\text { their viability; understand the implications of } \\
\text { and barriers to introducing new technology. }\end{array}$ \\
\hline Procurement & $\begin{array}{l}\text { Implementing change driven by investor } \\
\text { pressure; supply chain management; } \\
\text { assessing sustainability; benchmarking. }\end{array}$ & $\begin{array}{l}\text { Evaluate a fictional supermarket chain against } \\
\text { industry good practice in terms of corporate } \\
\text { social responsibility; review criteria for industry } \\
\text { benchmarking and develop proposals to ensure } \\
\text { approval by the ethical investment community. }\end{array}$ \\
\hline Plastic & $\begin{array}{l}\text { Implementing change through engaging with } \\
\text { public and stakeholders; understanding } \\
\text { barriers to implementing technical solutions; } \\
\text { sustainability definitions, tools, and } \\
\text { techniques; importance and methods of } \\
\text { stakeholder engagement; handling conflicting } \\
\text { viewpoints; unbiased information for } \\
\text { decision making. }\end{array}$ & $\begin{array}{l}\text { Recommend steps for engaging with the public } \\
\text { and other stakeholders regarding construction of } \\
\text { a new PVC recycling facility, in the north west } \\
\text { UK; having identified the key controversial } \\
\text { issues surrounding the suitability and safety of } \\
\text { PVS as a material, presenting this to the public } \\
\text { in a clear and balanced way using the format of } \\
\text { a short information leaflet. }\end{array}$ \\
\hline Water & $\begin{array}{l}\text { Mechanisms for change within a large } \\
\text { organisation; commercial pressures as a } \\
\text { barrier to and a driver for change; accurate } \\
\text { product information for change in consumer } \\
\text { behaviour; corporate social responsibility and } \\
\text { the supply chain; social, environmental and } \\
\text { economic factors; handling conflicting } \\
\text { viewpoints of different stakeholders; } \\
\text { unbiased information for consumers. }\end{array}$ & $\begin{array}{l}\text { Evaluate the feasibility and desirability of a } \\
\text { 'virtual water' labelling scheme within a high } \\
\text { street commercial food retailer; present this } \\
\text { evaluation in a range of summary formats, } \\
\text { suitable for commercial decision making, but } \\
\text { with a strong awareness of the different } \\
\text { viewpoints of a range of key stakeholders } \\
\text { connected to this private enterprise; apply } \\
\text { sustainable development principles to a } \\
\text { contentious and challenging practical issue in an } \\
\text { easily comprehensible, non-technical format. }\end{array}$ \\
\hline
\end{tabular}




\begin{tabular}{|l|l|l|}
\hline Food & $\begin{array}{l}\text { Supply chain management; supply chain } \\
\text { carbon footprint reduction; reducing food } \\
\text { waste; implementing change through new } \\
\text { technology; cost saving as a driver for } \\
\text { change; cost-benefit analysis. }\end{array}$ & $\begin{array}{l}\text { Outline possible strategies for how an agri- } \\
\text { corporation could introduce a novel real-time } \\
\text { tracking service to the food and perishable crops } \\
\text { supply chain and extract a financial return from } \\
\text { it; identify overhead costs which would need to } \\
\text { be covered, including: managing the activity, } \\
\text { providing \& servicing the equipment, training in } \\
\text { its use, help-desk support and steerage of the on- } \\
\text { going R\&D development programme. }\end{array}$ \\
\hline Dig & $\begin{array}{l}\text { How legal instruments can both foster and } \\
\text { hinder change; how different stakeholder } \\
\text { groups resist and favour different } \\
\text { mechanisms of change; how system wide } \\
\text { mechanisms can accommodate change; } \\
\text { CSR to support sustainable development; } \\
\text { how the law can underpin sustainable } \\
\text { development; economic, social, and } \\
\text { environmental aspects of sustainable } \\
\text { development within firms. }\end{array}$ & $\begin{array}{l}\text { Identify the scope and implications of the } \\
\text { requirements in the companies act 2006 for UK } \\
\text { multinational companies in the mining and } \\
\text { natural resources sector; in addition to the } \\
\text { identification of legal requirements, the exercise } \\
\text { requires recognition of key CSR issues and } \\
\text { consideration of how these issues can be } \\
\text { accommodated within a multi-stakeholder } \\
\text { setting of competing interests. }\end{array}$ \\
\hline
\end{tabular}

